
${ }^{\circ}$ Heming, A. E., Holtkamp, D. E., Kerwin, F., Mansor, L. F., and
Dacanay, J. G., Proc. Soc. Exp. Biol. Med., 80, 154 (1952).

${ }^{31}$ Hertz, R., Allen, M. J., and Tullner, W. W., Proc. Soc. Exp. Biol.

${ }^{33}$ Hertz, R., Allen, M. J., Tullner, W. W., and Westfall, B. B., Proc. Soc. Exp. Biol. Med., 79, 42 (1952).

${ }^{32}$ Hertz, R., Bergenstal, D. M., Lubs, H. A., and Jackson, J. J., Cancer 10, 765 (1957).

${ }^{34}$ Hertz, R., Pittman, J. A., and Graff, M. M., J. Clin. Endocrinol. and Med., 16, 705 (1956).

${ }^{35}$ Hortz, R., Tullner, W. W., and Allen, M. J., Proc. Soc. Exp. Biol. Med., irn, 480 (1951).

${ }^{36}$ Hertz, R., Tullner, W. W., Schnicker, J. A., Dhyse, F. G., and Hallman, L. H., Rec. Prog. in Hormone Res., 11, 119 (1956).

${ }^{27}$ Hogness, J. R., Lee, N. D., and Williams, R. H., Endocrinol., 52, $378(1952)$

${ }^{38}$ Hogness, J. R. Williams, R. H., and Lanec, M., Proc. Soc. Exp.

Holzbauer, M., J. Endoc., 14, 26 (1956).

${ }^{\circ}$ Jenkins, J. S., Meakin, J. W., Nelson, D. H., and Thorn, G. W., Science, 128, 478 (1958).

1 Jenkins, J. S., Meakin, J. W., and Nelson, D. H., Endocrinol., 64, $572(1959)$

" 2 Johnson, J. K., Remmers, A. R., Gregory, R., and Clayton, G. W., J. Lab. Clin. Med., 48, 822 (1956)

${ }^{33}$ Kuchmeister, H., Pleiss, G., and Wilhelm, W., Acta Endoc., 20, 39 (1955). "1 Larson, P. S., Hennigar, G. R., Finnegan, J. K., Smith, R. B., and
Haag, H. B., J. Pharm. Exp. Therap., 115, 408 (1955).

${ }^{45}$ Leone, L. A., Hahn, H., and Mellette, S. J., Virginia J. Seience, '7, 334 (1956).

${ }^{4 B}$ Lewis, L. A., and Page, I. H., Amer. J. Physiol., 173, 359 (1953).

${ }^{47}$ Liddle, G. W., Island, D., Lance, E. M., and Harris, A. G., J. Clin.

${ }^{4}$ Little, M. J., Kelsey, W. M., and Yount, E. H., Amer. J. Physiol., 185,159 (1956).

49 Mach, R. S., and Muller, A. F., Schweiz. Med. Wschr., Supr., 60, 406 (1957).

${ }^{50}$ Marks, B. H., Alpert, M., and Kruger, F. A., Endoc., 63, 75 (1958).

st Max, R., Muller, S., and Muller, A., Schweiz. Med. Wschr., 87, 406 (1957).

${ }^{52}$ McCullagh, E. P., and Tretbar, H. A., J. Clin. Endoc., 18, 134 (1958).

${ }^{53}$ Naidoff, D., Pincus, I. J., Town, A. E., and Scott, M. E., Amer. J. Ophthal., 39, 510 (1955).
${ }^{54}$ Nelson, A. A., and Woodard, G., Arch. Path., 48, 387 (1949).

${ }^{55}$ Newcomer, W. S., Amer. J. Physiol., 196, 276 (1959).

${ }^{56}$ Nichols, J., Davis, C., and Green, H. D., Endocrinol., 53, 541 (1953).

${ }^{57}$ Nichols, J., and Gardner, L. I., J. Lab. Clin. Med., 37, 229 (1951).

${ }^{58}$ Nichols, J., and Green, H. D., Amer. J. Physiol., 176, 374 (1954).

${ }^{50}$ Nichols, J., and Hennigar, G., J. Clin. Endoc. Med., 16, 956 (1956).

${ }^{60}$ Nichols, J., and Hennigar, G., Endocrinol., 61, 226 (1957).

${ }^{6 x}$ Nichols, J., and Hennigar, G., Exp. Med. Surg., 15, 310 (1957).

${ }^{2}$ Nichols, J., Kaye, S., and Larson, P. S., Proc. Soc. Exp. Biol. Med.,

${ }^{63}$ Nichols, J., and Sheehan, H. L., Endocrinol., 51, 362 (1952).

${ }^{61}$ Canad. Med. Assoc. J., 78, 357 (1958).

${ }^{65}$ Renold, A. E., Crabbe, J., Hernando-A vendano, J., Nelson, D. H., Ross, E. J., Emerson, K., and Thorn, G. W., New Eng. J. Med., 256,16 (1957).

${ }^{66}$ Rosenfeld, G., and Bascom, W. D., J. Biol. Chem., 222, 565 (1956).

${ }^{87}$ Sachsse, B., Med. Klin., 49, 1254 (1954).

"Schricker, J. A., Fisher, G. R., Tullner, W. W., and Hertz, R., Endocrinol., 51, 394 (1952). "Selenkow, H., Rivera, W. A., and Thorn, G. W., J. Clin. Endoc. Med.,
17, 1131 (1957).

${ }^{70}$ Sheehan, H., Summers, V. K., and Nichols, J., Lancet, 1, 312 (1953).

${ }^{71}$ Stoner, H. B., Nature, 172, 1044 (1953).

${ }^{73}$ Taliaferro, I., and Leone, L., New Eng. J. Med., 257, 855 (1957).

${ }^{73}$ Thorn, G. W., Renold, A. E., Goldfein, A., Nelson, D. H., Reddy, W. J., and Hertz, R., New Eng. J. Med., 254, 547 (1956).

$"$ Tornblom, N., Acta Med. Scand., 152, 149 (1956).

${ }^{75}$ Tornblom, N., Acta Med. Scand., 164, 23 (1959).

${ }^{76}$ Tullner, W. W., Graaf, M. M., and Hertz, R., Endocrinol., 58, 802 (1956).

${ }^{77}$ Verne, J., and Wegmann, R., C.R. Soc. Biol. (Paris), 146, 1044 (1952). Verne, J., and Wegmann, R., Cong. Assoc. Francaise Adv. des Sciences (1954)

Vilar, O., and Tullner, W. W., Endocrinol., 65, 80 (1959).

Weber, A. F., Bell, J. T., and Seller, A. F., Amer. J. Vet. Med., 19, (1)

Endoc., 14, 25 (1958).

Zimmerman, B., Bloch, H. S., Williams, W. L., Hitcheock, C. R., and Hoelscher, B., Cancer, 9, 940 (1956).

Kagawa, C. M., Sturtevant, F. M., and Van Arman, C. G., J. Pharm. Exp. Therap., 126, 123 (1959)

${ }^{81}$ Cella, J. A., and Kagawa, C. M., J. Amer. Chem. Soe., 79, 4808 (1957).

\title{
OBITUARIES
}

\section{Dr. W. Lawrence Balls, C.M.G., C.B.E., F.R.S.}

Dr. LAWRENCE BaLLS, who died on July 18, was the foremost of many workers who have been engaged on the development of Egyptian cotton during the present century. His personal investigations have been of great practical importance as well as of outstanding scientific interest. In addition to providing scientific knowledge, he markedly influenced the administrative procedures in Egypt for making that knowledge effective.

William Lawrence Balls was born in 1882. After being educated at King Edward VI School, Norwich, and St. John's College, Cambridge (of which he was a Fellow from 1909 until 1913), he became botanist to the Khedivial Agricultural Society in 1904 and served that body and (later) the Egyptian Department (later Ministry) of Agriculture until his retirement in 1947, except for a period 1915-26, when he was designer and head of the Experimental Department of the (then) Fine Cotton Spinners' Association, Ltd., at Bollington, Cheshire.

During the first phase of his career in Egypt, Balls made detailed physiological studies of the growth of the cotton plant and of the mode of development of the fibres produced from the seeds-the raw cotton of commerce. Many of the results of these fundamental investigations are summarized in his now classical works "The Cotton Plant in Egypt" (1912) and "The Development and Properties of Raw
Cotton" (1915). He also made som 9 of the earliest critical genetical studies of plant characteristics and features of fibre quality, and rapidly formed the conclusion that mediocrity and degeneration in both yield and quality were inevitable under Egyptian conditions unless genetic variability was minimized and controlled. From this arose his concept of "pure line' strains. This work led to the development of methods for making available pure-line seed supplies. During his later career in Egypt, as chairman of the Cotton Research Board of the Ministry of Agriculture, Balls gave continuous encouragement to the policy of crossing and re-crossing of the various strains to exploit to the full the latent characteristics inherent in Egyptian cotton and persisting from the original historical medley of impure cottons.

From the start of his career, Balls was actively interested, in the physiological requirements of the cotton plant, and this led him to study the water and drainage requirements for optimum yield under Egyptian irrigated conditions, with the results described in "The Yield of a Crop" (1953). In this work he arrived at the valuable, though possibly depressing, conclusion that the improvements in crop yield made over the years, by himself and his co-workers through better pest control, improved manuring, the development of more prolific strains, etc., had only made it possible to counterbalance approximately the progressive losses caused by the water-logging of the soil associated with the increase 
in the water-table following the change from the basin type of irrigation to perennial irrigation.

In considering fibre quality, Balls took as his endpoint the quality of the spun yarn, and this interest, together with the circumstances of his career, led him into spinning technology. His "Handbook of Spinning Tests for Cotton Growers" (1920) was a pioneer work that needs little amendment to-day. His "Studies of Quality in Cotton" (1928), based on research work done at Bollington and describing notably the 'drafting wave' and the 'Rule' spinning frame, has influenced much of later technological research and development.

Balls was active to the end, and it was a pleasure to delegates at the Jubilee Conference of the Textile Institute (which had awarded him an honorary fellowship in 1943) in May of this year, to hear from the master himself a paper on the "Beginnings of Botany on a Cotton Crop".

Dr. Lawrence Balls was a great man, in the true sense of the words, who made for himself a career and won by his ability international recognition in a little-known and, at that time, little-regarded field of investigation. D. W. HiLL

\section{Prof. J. Brontë Gatenby}

Prof. James Brontë Gatenby, the eminent cytologist, died on July 20 while on holiday at Galway, Ireland. Born in 1892 in New Zealand, he developed a keen interest in entomology and this led him to correspond with Prof. F. B. Poulton in Oxford, where he later went as a student and studied under Prof. E. S. Goodrich. His interest in entomology was reflected in many of his later papers. He graduated in 1916 with first-class honours and was appointed lecturer in histology in Prof. (later Sir Charles) Sherrington's Physiology Laboratory. He soon became interested in cytology, particularly in the inclusions of the germ cells of a wide variety of animals, and he published a long series of papers on this subject. In 1918 he was appointed to a senior demyship at Magdalen College, Oxford, and in 1919 lecturer in cytology in the University of London, where he worked with Prof. J. P. Hill. During these years he produced a considerable number of papers on the embryology, oogenesis and spermatogenesis of both invertebrates and vertebrates. His D.Phil. he obtained from Oxford and his D.Sc. from London.

In 1921 he was appointed to the chair of zoology and comparative anatomy in Trinity College, Dublin, a post which he held until 1959, when he was appointed to a research chair of cytology in the same University. During this period in Dublin he attracted students from all over the world, and he was involved in several fierce controversies relating to the Golgi apparatus-the cell inclusion which he studied in considerable detail. These controversies were mainly concerned with Parat's vacuome hypothesis and also with the question of whether or not the Golgi bodies in many cells were staining artefacts.

Since the Second World War, Gatenby took an increasing interest in electron microscopy. He became firmly convinced of the great potentialities of this technique two years ago when he worked for a while at the Argonne National Laboratory in the United States. He was, however, always insistent on linking this work with light microscope studies. This was his second visit to the United States-in 1930 he spent a year at Yale University as a Seessel Fellow. In 1933 he was appointed visiting lecturer to the University of Louvain.

He had a very extensive knowledge of microscopical techniques, and for many years was a joint editor of "The Microtomist's Vade Mecum". He was on the editorial board of the Journal of the Royal Microscopical Society and other learned journals, and was made an honorary member of a number of scientific societies.

To his students Gatenby appeared rather fearsome at times, but to keen and interested ones he gave every excouragement and showed much kindness. $\mathrm{H}$ a would stand for no sham or bluff. He was in many ways an outstanding representative of the old school of classical zoologists. His teaching and published work reflected his respect and affection for some of the great names of British zoology whom he knew well-Goodrich and Lankester in particular. By his death the world of eytology and zoology has lost an eminent man. $\mathrm{He}$ is survived by his second wife and four children by his first marriage.

\section{J. N. R. Gratnger}

\section{Prof. F. A. Jenkins}

Prof. Francis A. Jenkins, professor of physics in the University of California, died at his home in Berkeley on August 3, after an illness of two months. He was a graduate of the Universities of Chicago and Toulouse and had been a faculty member at Berkeley for thirty-one years. He had held Guggenheim fellowships at Utrecht, Uppsala and most recently at Oxford, where his presence and activity in the autumn of 1958 are warmly remembered at the Clarendon Laboratory, at Brasenose College, which made him a member, and by many friends and colleagues.

Jenkins's name is perhaps most widely known through the excellent text-book on optics, by Jenkins and White; but it is his research work, covering a wide field of optics and especially spectroscopy, which has established his reputation among physicists, chemists and astronomers everywhere. His chief contributions were in the field of molecular spectroscopy; of the numerous topics only some of the most important can be mentioned here: his thorough study of the CN bands and of perturbation effects in their rotational structure, the investigation of isotope effects and the determination of isotopic mass ratios $\left(\mathrm{Li}_{2}, \mathrm{BO}\right)$, his work on the intensity distribution in the rotational structure of bands and on the changes of coupling conditions as the result of increasing rate of rotation (NO), the determination of nuclear spins and nuclear statistics from alternating intensities (Se, $\mathrm{C}^{14}$ ) and the study of Rydberg series in band spectra.

In the field of atomic spectroscopy, his work on the quadratic Zeeman effect in sodium and potassium, of Zeeman effects in forbidden lines and on hyperfine structure and isotope shift is outstanding. He also made valuable contributions to spectroscopic methods, especially in the field of dielectric multi-layers, studying the performance of broad-band interference filters, the dispersion of the phase change in such filters and the ultra-violet reflectivity of multi-layers containing antimonous oxide and lead chloride. It was especially his knowledge and experience in this field from which the spectroscopy group in the Clarendon Laboratory derived great benefit during his stay there. 